\title{
AN ANALYSIS OF STUDENTS' ERROR IN WRITING SIMPLE SENTENCES
}

\author{
${\text { Budi Nugraha', }{ }^{1} \text { Maryani }}^{2}$ \\ ${ }^{1}$ IKIP Siliwangi \\ ${ }^{2}$ IKIP Siliwangi \\ ${ }^{1}$ budinugraha773@gmail.com, ${ }^{2}$ maryani.smpn27@gmail.com
}

\begin{abstract}
Abstrac
Language is needed whether it is written or spoken. Language is very necessary for people as a mean of communication. The objective of this research was to analyze the students' ability in writing simple sentences in past tense. This research used qualitaive research and the data were analyzed to investigate the second year of students' ability in writing English simple sentences. The participant of this research was consisted of 32 students. Data analysis shows that $27.81 \%$ the students have difficulties in structure English simple sentence in past tense. Furthermore $38.12 \%$ the students have difficulties using regular verbs in past tense, whereas $71.8 \%$ the students have difficulties using irregural verbs in past tense. Over all, the students' ability in writing English simple sentence in past tense can be considered in medium level. This is due to their confusion in using verb (regular verbs and irregular verbs).
\end{abstract}

Keywords: Analysis, Writing, Simple Sentence

\section{INTRODUCTION}

Language is essential for human. We use spoken language every day face to face as a means of communication written language allows us to record and hold on to our history across generation (Kaswan 2010:1). People need langauge to communicate their thought to the other. Language is used to convey opinion, feeling or idea. It is also used to get information or share information. Language is needed whether it is written or spoken. Language is very necessary for people as a mean of communication.

It is known that English is an internatioonal language and it is the first foreign language in indonesia used to communicate throughout the country. Therefore, as an international language English is necessary to be mastered by genration of a nation,especially for students in order to be able to adapt and compete in the international world, because by studying english they can get many advantages such as science and technology development.

Like other developing nations, Indonesia has also included the teaching of English as a first foreign language learned at school. English also has been one of the compulsory subjects studied from secondary schools up to university level. However, many students get difficulties in learning English because English is considered as foreign language in indonesia and aslo it is known that most part of English grammatical systems are different fom indonesian. Then, the writer believes that their knowledge on the first or second language interferetheir Englis. Hence, students get difficulties in learning English. Moreover, the linguistic system of English is considered complicated (Oshima and Houge, 1998)

Blanchard and Root (1998: 1) in Mundriyah and Parmawati (2016) state that learning to write in a new language is not always easy.Nunan (1989:88) states that writing is a form of communication and process of expressing ideas into a product of writing; translating ouit 
thought into language. Writing becomes successful when the reader catches a glimpse of the hidden speaker behind the text; when a phrase, a sentence, a few words reveal the human subject's intentions and presence. Writing is a process and product activity (Brown, 2001:12). Meanwhile, Westwood (2008: 26) states that "writing enchances language acquisiton as learner experiments with words, sentences, and larger chunks of writing communication their ideas effectively and to reinforce the grammar and vocabulary they are learning in the class"

Furthermore, Nunan (1991:91, in Apsari, 2017) states that there are three stages of writing. They are pre-writing, writing, and post-writing. The elements of writing are the various skillls that are needed for most types of academic writing, whether it is a short report, a long essay or a dissertation (Gilbert, 1989:15), therefore good writing in English requires the ability to organize idea logically into sentences,paragraphs or essays. In English, there are several kinds of sentences according to the num ber of predicates; they are simple, compound, complex, compound-complex or double sentences. This research only focuses on simple sentence. A simple sentence is one independent clause. Common characteristics simple sentence is a simple sentence has only subject + verb arrangement. In this research focused on past tense. There are sixteen tenses in English, and past tense is one of them. The functions of simple pastense are talk about activities that began and ended in the past for example : I watched TV beofre $i$ slept last night. Second it is used to talk about past habit, for example : we always played football in the afternoon when we were child (Azar, 1989:20). The past tense indicates definite events happened in the past. There are many definitions of past tense. According to Frank (1996:73) the past tense indicates definite time terminating in the past,whether a time word is given or not. Simple past is used for describing act that have already been concluded and whose exact time occurence is known. Furthermore, simple past is used for retelling successive events. The simple past tense is the most common tense in Englis. The simple past tense is formed by using the simple past form of the verb. Finally, for the regular verb, the past form is made by adding - ED to the verb (Azar, 2003:18) for example finish $=$ finished, stop = stopped, play = played etc.

\section{METHOD}

In this study the writers used qualitative methods. The qualitive method was employed because this study focused on material development in the form of writing course. Qualitative descriptions can play the important role of suggesting posible relationship(s), causes, effects, and even dynamic processes in school settings. Qualitative methods can highlight subtleties in pupil behaviour and response, illuminate reasons for action and provide indepth information on teacher interpretations and teaching style (Burns, 1994:14).

\section{RESULTS AND DISCUSSION}

\section{Results}

The researcher analyzed regular and irregular verbs feature to find out the students' ability in writing English simple sentences in past tense. The result of data analyzed can be seen in the table below:

Table 1. The result of students error in writing English simple sentences in past tense

\begin{tabular}{ccccccc}
\hline No & Name & Structure & Regular & Irregular & Total Error & $\boldsymbol{\%}$ \\
\hline $\mathbf{1}$ & Student 1 & 2 & 2 & 4 & 8 & 40 \\
\hline $\mathbf{2}$ & Student 2 & 1 & 2 & 4 & 7 & 35
\end{tabular}




\begin{tabular}{cllllll}
\hline $\mathbf{3}$ & Student 3 & 3 & 1 & 3 & 7 & 35 \\
\hline $\mathbf{4}$ & Student 4 & 2 & 2 & 3 & 7 & 35 \\
\hline $\mathbf{5}$ & Student 5 & 4 & 4 & 5 & 13 & 65 \\
\hline $\mathbf{6}$ & Student 6 & 1 & 1 & 4 & 6 & 30 \\
\hline $\mathbf{7}$ & Student 7 & 7 & 5 & 4 & 16 & 80 \\
\hline $\mathbf{8}$ & Student 8 & 5 & 5 & 5 & 15 & 75 \\
\hline $\mathbf{9}$ & Student 9 & 5 & 4 & 4 & 13 & 65 \\
\hline $\mathbf{1 0}$ & Student 10 & 1 & 3 & 8 & 12 & 60 \\
\hline $\mathbf{1 1}$ & Student 11 & 2 & 2 & 3 & 7 & 35 \\
\hline $\mathbf{1 2}$ & Student 12 & 3 & 4 & 4 & 11 & 35 \\
\hline $\mathbf{1 3}$ & Student 13 & 2 & 2 & 2 & 6 & 30 \\
\hline $\mathbf{1 4}$ & Student 14 & 0 & 1 & 4 & 5 & 25 \\
\hline $\mathbf{1 5}$ & Student 15 & 0 & 1 & 1 & 2 & 10 \\
\hline $\mathbf{1 6}$ & Student 16 & 2 & 2 & 3 & 7 & 35 \\
\hline $\mathbf{1 7}$ & Student 17 & 2 & 2 & 3 & 7 & 35 \\
\hline $\mathbf{1 8}$ & Student 18 & 4 & 1 & 3 & 8 & 40 \\
\hline $\mathbf{1 9}$ & Student 19 & 3 & 1 & 3 & 7 & 35 \\
\hline $\mathbf{2 0}$ & Student 20 & 2 & 0 & 4 & 6 & 30 \\
\hline $\mathbf{2 1}$ & Student 21 & 4 & 1 & 2 & 7 & 35 \\
\hline $\mathbf{2 2}$ & Student 22 & 5 & 2 & 4 & 11 & 55 \\
\hline $\mathbf{2 3}$ & Student 23 & 3 & 1 & 3 & 7 & 35 \\
\hline $\mathbf{2 4}$ & Student 24 & 5 & 2 & 5 & 12 & 60 \\
\hline $\mathbf{2 5}$ & Student 25 & 0 & 0 & 4 & 4 & 20 \\
\hline $\mathbf{2 6}$ & Student 26 & 2 & 1 & 4 & 7 & 35 \\
\hline $\mathbf{2 7}$ & Student 27 & 2 & 1 & 2 & 5 & 25 \\
\hline $\mathbf{2 8}$ & Student 28 & 3 & 1 & 3 & 7 & 35 \\
\hline $\mathbf{2 9}$ & Student 29 & 2 & 1 & 3 & 6 & 30 \\
\hline $\mathbf{3 0}$ & Student 30 & 4 & 1 & 3 & 8 & 40 \\
\hline $\mathbf{3 1}$ & Student 31 & 1 & 3 & 4 & 8 & 40 \\
\hline $\mathbf{3 2}$ & Student 32 & 4 & 2 & 4 & 10 & 50 \\
\hline & Total & 87 & 61 & 115 & 263 & 41
\end{tabular}

a) Percentage error of structure

$\mathrm{P}=$ Error of structure $\mathrm{X} 100 \%$

$10 \times 32$

$\mathrm{P}=\underline{87} \mathrm{X} 100 \%=27.18 \%$

320

b) Percentage error of regular verbs

$\mathrm{P}=\underline{\text { Total error of regular } \mathrm{X} 100 \%}$

$$
5 \times 32
$$

$\mathrm{P}=\underline{61} \times 100 \%=38.12 \%$

160

c) Percentage error of irregular verbs

$\mathrm{P}=\underline{\text { Total error of irregular } \mathrm{X} 100 \%}$

$$
5 \times 32
$$




$$
\mathrm{P}=\frac{115}{160} \times 100 \%=71.87 \%
$$

\section{Discussion}

In this research, the writers used qualitative method to analyze the students ability in writing simple sentences that consist of 32 students. The data shows that $27.18 \%$ students did not understand about structure of English simple sentence in past tense. Furthermore 38.12\% students did not understand how to used regular verbs, whereas $71.87 \%$ students did not understand and how to use irregular verbs. Based on the result the researcher indicates that the students considered in medium level.

\section{CONCLUSION}

The aim of the research is to analyze the students ability in writing simple sentences. The result of data showed that most of students can be considered in medium level. In conclusion, although this is the simplest form of the sentence the students are still having difficulties. This research is expected to be able to enrich the students knowledge to improve their understanding of English structure and to be aware of grammatical differences between Indonesian and English. Moreover the results of this study are expected to facilitate students in learning especially writing English simple sentences. So the research is expected to provide motivation and encourage other researchers to conduct further research and efforts to reveal the factors that research results can be more comprehensive. The results of this study are also expected to contribute to the development of English writing.

\section{ACKNOWLEDGMENTS}

First of all, the writer would like to say hamdallah and thanks to Allah SWT who was give us blessing in writing this article.

\section{REFERENCES}

Apsari, Y. (2017). the Use of Picture Series in Teaching Writing Recount Text. ELTIN JOURNAL, Journal of English Language Teaching in Indonesia, 5(2), 51. https://doi.org/10.22460/eltin.v5i2.p51-56

Azzar, Betty S (2003). Fundamental of English Grammar. New York:Pearson Education Ltd.

Brown, J.D. (2001). Teaching by Principles: An Interactive Approach to Language Pedagogy ( $2^{\text {nd }}$ Edition). New York: Addison Wesley Longman Inc.

Burns. R.B. (1994). Introsuction to Reasearch Method. Australia: Longman Australia Pty Ltd.

Frank, B. S. (1996). "Unit, Symbols, and Terminology for Plan Physiology: A Reference for Presentation of Reasearch Result in The Plant Sciences. New York. Oxford University Press.

Gilbert, Pam. (1989). Writing, Schooling, and Deconstruction. New York: Routledge Inc,

Kaswan, (2010). A Brief Introduction to Language Acquisition. Bandung: STKIP Siliwangipress.

Mundriyah, M., \& Parmawati, A. (2016). Using Think-Pair-Share (Tps) To Improve Students'writing Creativity (A Classroom Action Research In The Second Semester Students Of Stkip Siliwangi Bandung). P2m Stkip Siliwangi, 3(2), 84-91. 
Nunan, D. (1989). Second Language Teaching and Learning. USA: Heinle\&Heinle Publisher. Cambridge

Oshima, A, and Hogue, A. (1998). Writing Academic English ( $3^{\text {rd }}$ Edition). New York: Pearson Education Publication Data

Westwood, Peter. (2008). What Teacher Need to Know about Reading and Writing difficulties. Victoria: ACER Press. 